\title{
EGPS - nowe możliwości na drodze kształcenia przyszłych tłumaczy (sprawozdanie)
}

Program European Graduate Placement Scheme (w skrócie EGPS) to międzynarodowy projekt finansowany przez Komisję Europejską, którego celem jest stworzenie studentom specjalności tłumaczeniowych możliwości odbycia zagranicznych praktyk w firmach będących partnerami programu.

\section{Podstawowe cele i założenia programu EGPS}

$\mathrm{W}$ artykule Translating study into jobs opublikowanym w czasopiśmie „The Linguist" Helen Astley, kierownik projektu EGPS, pisze, że impulsem do stworzenia programu był wielki sukces, jakim w Wielkiej Brytanii cieszył się prototypowy dla EGPSu program UK Graduate Placement Scheme. Po zakończeniu praktyk tłumaczeniowych organizowanych za jego pośrednictwem dwie trzecie studentów otrzymywało ofertę stałej pracy w firmach przyjmujących ich na praktyki (por. Astley 2013/2014). Rozwinięcie projektu na skalę międzynarodową było naturalnym krokiem naprzód i pomysłem genialnym w swej prostocie: możliwości, jakie stwarza otwarcie granic, zostały wykorzystane dla rozwoju nauki (w tym wypadku dla teorii przekładu) oraz jej praktycznego zastosowania na rynku tłumaczeniowym. Brytyjska organizacja Skills CFA przy współpracy z czterema uniwersytetami partnerskimi: z Wielkiej Brytanii (University of Salford), Hiszpanii (Universidad Autònoma de Barcelona), Niemiec (Johannes Gutenberg-Universität Maintz) i Polski (Uniwersytet Pedagogiczny im. KEN w Krakowie) umożliwia studentom odbycie za granicą stażu przewidzianego w toku ich studiów. W pierwszej kolejności ma się to przyczyniać do zwiększenia mobilności studentów specjalności tłumaczeniowych, co w tej branży wydaje się bardzo istotnym elementem edukacji. Poza znakomitą znajomością języka, który jest oczywiście podstawowym narzędziem pracy tłumacza, zawód ten wymaga innych umiejętności i zdolności, z których wielu nie uda się wykształcić w uczelnianych salach i pracowniach komputerowych. Oprócz języka tłumacz powinien znać kulturę, system społeczny i polityczny, zwyczaje i normy zachowań 
(w tym również etykietę biznesową) kraju, w którym obowiązuje drugi język tłumacza.

Bycie tłumaczem to profesja bardzo prestiżowa, ale też i wymagająca. Zwłaszcza tłumaczy specjalności biznesowych powinna cechować gotowość do wyjazdów, chęć poznawania tego, co nowe i nieznane, otwartość na ludzi. Projekt EGPS daje młodym ludziom szansę na to, by jeszcze $\mathrm{w}$ trakcie studiów zdobyli doświadczenie zawodowe w środowisku międzynarodowym, autentycznym, wśród profesjonalnych tłumaczy i by zweryfikowali tym samym swoje umiejętności i predyspozycje do wykonywania tego zawodu. To z kolei ułatwi im - jak podkreślają twórcy programu - sprawdzenie siebie, upewnienie się co do słuszności wyboru drogi życiowej, a w przyszłości także znalezienie zatrudnienia $\mathrm{w}$ interesującym ich sektorze usług językowych i tłumaczeniowych.

\section{Kiedy teoria spotyka się z praktyką...}

Nie tylko w Polsce (co często zarzuca się polskiemu systemowi edukacji), ale na całym świecie istnieje wyraźny rozdźwięk między edukacją na poziomie uniwersyteckim a wymaganiami stawianymi młodym ludziom przez późniejszych pracodawców. Dla obu stron ta ogromna przepaść pomiędzy oczekiwaniami a rzeczywistością bywa powodem rozczarowań i frustracji. Pracodawcy narzekają na kompletne nieprzystosowanie świeżo upieczonych absolwentów do pracy w zawodzie, ci drudzy z kolei często są zwyczajnie przytłoczeni stawianymi im wymogami. Coraz częściej też sami studenci zauważają, że uczyć się przekładu i pracować w zawodzie tłumacza to dwie różne rzeczy i na własną rękę poszukują sposobów na zdobycie doświadczenia jeszcze w czasie studiów. W ten sposób starają się polepszyć swoją pozycję na bardzo konkurencyjnym rynku pracy. Wielu studentów pracuje zawodowo już w czasie studiów, nie zawsze jednak jest to praca w wyuczonym zawodzie. W dodatku bardzo często koliduje ona $\mathrm{z}$ nauką. W pewnym sensie program EGPS wychodzi naprzeciw oczekiwaniom młodych ludzi i ułatwia im dotarcie do ofert odpowiednich pracodawców, nie zaburzając jednocześnie toku studiów. Praktyka przekładu jest niezbędnym uzupełnieniem dla jej teorii (wciąż dominującej w planach studiów na polskich uczelniach). Nie chodzi tu jednak wyłącznie o długie godziny spędzone na samodzielnym tłumaczeniu zadanych tekstów i omawianiu ich z prowadzącym zajęcia (choć i to jest niezmiernie ważne), ale przede wszystkim o zdobycie konkretnego doświadczenia zawodowego. Nie przesadzimy chyba, nazywając je bezcennym, ponieważ zagra- 
niczny staż w renomowanej firmie będzie z całą pewnością mocnym punktem w CV absolwenta poszukującego swojego miejsca na rynku pracy. Co więcej, to właśnie tego typu doświadczenie może sprawić, że ten, a nie inny młody człowiek przykuje uwagę przyszłego pracodawcy. Mimo że żyjemy w czasach globalizacji, a podróże stały się naszą codziennością, to doświadczenie zawodowe zdobyte $\mathrm{w}$ prawdziwie międzynarodowym środowisku pozostaje wciąż cennym i niestety niecodziennym atutem młodego pracownika. System praktyk zaplanowanych i rozliczanych zarówno przez pracodawców przyjmujących studenta, jak i uczelnianych koordynatorów EGPS sprawia, że studenci rozwijają nie tylko swoje kompetencje tłumaczeniowe, ale także wiele innych przydatnych w późniejszym życiu zawodowym. Uczą się oni m.in. wpisanej w zawód tłumacza pracy pod presją czasu i związanej z nią konieczności dotrzymywania terminów, a także umiejętności współpracy w grupie, sztuki negocjacji, ogólnie przyjętych standardów obsługi kontrahentów z firm partnerskich oraz klientów indywidualnych i umiejętności sprostania ich różnym oczekiwaniom. Tego typu staż szkoli młodych ludzi również w zakresie brania odpowiedzialności za wykonywane zadania, staranności i dbałości o jakość wykonywanej pracy, którą w trakcie praktyki całkiem serio firmują swoim nazwiskiem. Daje on też z całą pewnością poczucie wartości oraz pewność siebie, a to - jak zapewnia Chus Fernandez z University of Salford - sprawia, że studenci mający prawdziwe doświadczenie zawodowe w cieszącej się renomą zagranicznej firmie łatwiej znajdują zatrudnienie i są bardziej chętni do podjęcia wyzwania, jakim jest praca za granicą (por. Astley 2013/2014).

\section{Kto, gdzie i kiedy, czyli praktyczna strona praktyk}

Oferta praktyk w ramach programu EGPS z założenia skierowana jest do studentów kierunków takich jak lingwistyka stosowana czy neofilologie ze specjalnością tłumaczeniową. Ponieważ od kandydatów oczekuje się bardzo dobrej znajomości języka obcego (preferowany poziom to co najmniej C1), za najlepszy moment na wyjazd można uznać wakacje między pierwszym a drugim rokiem studiów II stopnia. Nie ma tu jednak bardzo rygorystycznie określonych granic. Czynnikiem decydującym w każdym przypadku jest bowiem poziom znajomości języka obcego. To firmy biorące udział w programie na podstawie nadesłanych im CV kandydatów decydują, kogo przyjąć na staż, a kogo odrzucić. Zatem już na poziomie rekrutacji student jest traktowany na równi z pozostałymi pracownikami firmy. Również potem, w trakcie praktyki jest rozliczany z powierzonych mu zadań i oceniany na podstawie 
tych samych kryteriów jak reszta zatrudnionych. To naprawdę duże wyzwanie dla młodego człowieka, ale i niepowtarzalna szansa na sprawdzenie tego, jak się wypada na tle zawodowców. Najlepszym czasem na odbycie stażu jest lato - czas wakacji, okres wolny od zajęć na uczelni. Można wtedy wyjechać nawet na trzy miesiące i nie jest konieczne uzyskanie od uczelni specjalnej zgodny na opuszczanie zajęć, która byłaby niezbędna (a niekiedy niemożliwa do zdobycia) w przypadku odbywania praktyki w czasie roku akademickiego. Praktyki EGPS współgrają z tokiem studiów, uzupełniają go, nie stanowią jednak zamiennika zajęć na uczelni. Student może oczywiście wyjechać na staż w czasie roku akademickiego, musi jednak wcześniej uzgodnić warunki zaliczenia przedmiotów z prowadzącymi zajęcia bądź wystąpić o przyznanie indywidualnego toku studiów.

Wszystkie formalności związane $\mathrm{z}$ wyjazdem pomogą studentowi wypełnić specjalnie przygotowani uczelniani koordynatorzy EGPS. Choć dziś studenci z Polski mogą odbywać praktyki w firmach w Wielkiej Brytanii, Hiszpanii i Niemczech, a w szczególnych wypadkach również w firmach w Polsce, to oferta EGPS skierowana jest nie tylko do studentów tych konkretnych filologii. Różne biura tłumaczeniowe potrzebują pracowników z wieloma innymi językami, a student np. rusycystyki czy romanistyki może wyjechać na praktykę do Niemiec czy Hiszpanii, jeśli jakaś tamtejsza firma będzie szukała stażysty z zaawansowaną znajomością języka rosyjskiego czy francuskiego. Należy przy tym pamiętać, że to na podstawie nadesłanego CV pracodawca dokona wyboru, warto więc przygotować je starannie, by już na wstępnym etapie okazać się profesjonalistą, a być może współpraca $\mathrm{z}$ daną firmą nie zakończy się wraz ze stażem.

Szczegółowe informacje na temat projektu EGPS oraz aktualności można znaleźć na oficjalnej stronie internetowej: http://www.e-gps.org/

Ewelina Kwiatek, Monika Zabrocka (Uniwersytet Pedagogiczny im. Komisji Edukacji Narodowej w Krakowie)

\section{Literatura}

Astley, H., 2013/2014, „Translating study into jobs”, [w:] The Linguist, No $52 / 6$, s. $20-21$, http://thelinguist.uberflip.com/h/i/2368686-the-linguist-52-6 (dostęp: 12 marca 2014 r.).

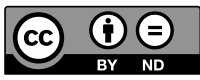

